\title{
The Eurasian eagle-owl (Bubo bubo) diet in the Trøndelag region (Central Norway)
}

\author{
Potrava výra skalného (Bubo bubo) v regióne Trøndelag (stredné Nórsko)
}

\author{
Ján OBUCH \& Georg BANGJORD
}

\begin{abstract}
Between 2008 and 2015 we collected pellets of the Eurasian eagle-owl (Bubo bubo) in the Trøndelag region of central Norway and identified the food remains in these samples. We collected material at 45 sites with samples from a total of 76 nests. Some of the samples were from older and already abandoned nests, but at several sites we also found and collected fresh $B$. bubo pellets. In total 40,766 items of prey were identified from the osteological material. The most dominant food components were mammals (Mammalia, 25 species, 63.5\%). The species representation of birds was very diverse (Aves, more than 150 species, 19.4\%). Of amphibians (Amphibia, 16.8\%), the well-represented species were Rana temporaria. Fish (Pisces, 0.3\%) were represented rarely, while invertebrates were represented only sporadically (Invertebrata, $0.05 \%$ ). A special composition was found in the diet spectra of the mammals and birds in the mountainous areas at altitudes between $220-780 \mathrm{~m}$ above sea level. The highest proportion of frogs was found in areas in the proximity of the mainland shore. On the northern islands located near the coast a significant proportion of the $B$. bubo diet consisted of rodents (Rodentia). On the more isolated southern islands of Frøya, Hitra and Storfosna the main prey was sea birds, and of the mammals there were also hedgehogs and rats.
\end{abstract}

Abstrakt: V rokoch 2008 až 2015 sme uskutočňovali zber a determináciu potravných zvyškov výra skalného (Bubo bubo) v kraji Trøndelag v strednom Nórsku. Získali sme zbery zo 45 lokalít, na ktorých boli odobraté vzorky zo 76 hniezd. Niektoré vzorky pochádzajú zo starších opustených hniezd, na niektorých lokalitách boli zbierané tiež čerstvé vývržky $B$. bubo. Z osteologického materiálu sme determinovali 40766 kusov potravy. Najpočetnejšou zložkou boli cicavce (Mammalia, 25 druhov, 63,5 \%). Vel’mi pestré je druhové zloženie vtáčej koristi (Aves, viac ako 150 druhov, 19,4 \%). Z obojživelníkov (Amphibia, 16,8 \%) bol početne zastúpený druh Rana temporaria. Ryby (Pisces, $0,3 \%$ ) boli zriedkavou súčastou potravy a sporadicky sa vyskytovali zvyšky bezstavovcov (Invertebrata, 0,05\%). Osobitné zloženie malo potravné spektrum cicavcov a vtákov v horských oblastiach $220-750$ m nad morom. Najvyšší podiel žiab bol zistený na územiach v blízkosti pevninského pobrežia. Na severnejšie položených ostrovoch v blízkosti pobrežia tvorili významnú čast' potravy $B$. bubo hlodavce (Rodentia). Na viac izolovaných južných ostrovoch Frøya, Hitra a Storfosna boli hlavnou korist’ou morské druhy vtákov, z cicavcov ježe a potkany.

Key words: Eurasian eagle-owl, Bubo bubo, diet, Norway

Ján Obuch, Comenius University in Bratislava, Botanical Garden, SK-038 15 Blatnica, Slovakia. E-mail: obuch@rec.uniba.sk. Georg Bangjord, Norwegian Ornithological Society, NO-7012 Trondheim, Norway. E-mail: bangjord@online.no.

Acknowledgement: We are very grateful to Ingar J. Øien of the Norwegian Ornithological Society, who has been our contact in this organisation and has contributed to our applications for project funding. We also wish to thank the following institutions which have been funding the project: Norwegian Environment Agency, County Governor of Sør-Trøndelag, Nord-Trøndelag and Nordland. Furthermore, we are greatly indebted to the persons who have contributed in different ways to the project, especially Lorentz Noteng, Martin Person, Sigurd Bangjord, Venke Ivarrud, Asgeir Østvik, Eva Tilseth, Morten Venås, Per Inge Værnesbranden, Marit Hegseth Rønning and Livar Ramvik. They have given information regarding nesting sites and have participated in searching for nests and resting sites, and in the collection of pellets and bones from the nest areas.

\section{Introduction}

The Eurasian eagle-owl is an extremely efficient and versatile raptorial bird (Willgohs 1974). This top predator also hunts smaller species of owls and birds of prey and beasts of prey up to the size of a fox. In this way it plays an important role in various ecosystems in which animals are reflected in the relative representation of its prey. Comparison of the various food compositions enable us to render changes over long periods and between years and types of living area. The first compilation of $B$. bubo diet studies in Norway was published by Hagen (1952). In total, the material consisted of 780 individual 
items of prey, mostly found in the inner parts of the country. A more extensive study of the $B$. bubo food remains from 82 sites (28 nesting places) collected between 1957-1972 was presented $(\mathrm{n}=4456)$ by Willgohs (1974). Most of the sites were located on the west coast, and approximately $85 \%$ of the material was from the Hordaland and Sogn og Fjordane counties. In neighbouring Sweden the diet of $B$. bubo has been researched by Regnell (1957), Höglund (1966), Schaefer (1970), Emmet et al. (1972) and Olsson (1979).

The main goal of our research was to determine the differences in the composition of the $B$. bubo diet between the islands, near the mainland shore and in the mountainous areas of the Trøndelag region of Central Norway.

\section{Materials and methods}

In this article we evaluate the differences in the representation of species in the prey of $B$. bubo between the municipalities of Sør-Trondelag and Nord-Trøndelag counties. In order to protect the nesting sites we will not specify names of specific locations. Their locations are shown in the attached map (Fig. 1). Descriptions of the natural conditions in the municipalities are mentioned in the Tab. 1. Additional and more extensive data from this study will be presented in a later report by the same authors in a journal published by the Norwegian Ornithological Society.

While locating the nesting sites we consulted some ornithologists as well as historical records. In some localities one $B$. bubo breeding pair used several sites for

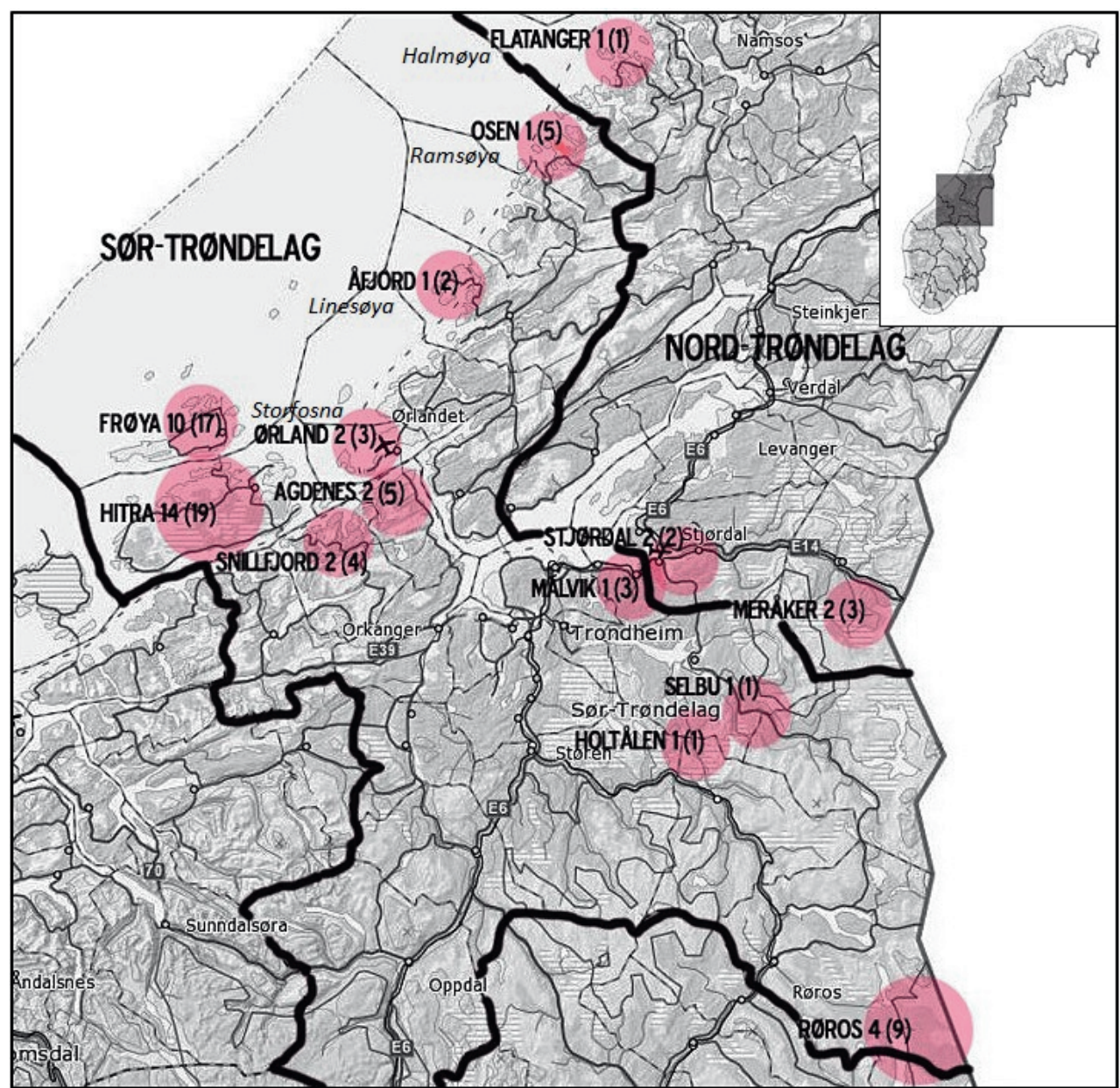

Fig. 1. Map of the study area. Next to the name of each municipality is the number of territories and in parentheses is the number of nests.

Obr. 1. Mapa študovaného územia. Vedla názvu samosprávy je uvedený počet teritórií a v zátvorkách počet hniezd. 
Tab. 1. Description of the study areas.

Tab. 1. Opis študovaných území.

\begin{tabular}{|c|c|c|}
\hline $\begin{array}{l}\text { municipality / } \\
\text { okres }\end{array}$ & $\begin{array}{l}\text { habitats / } \\
\text { habitaty }\end{array}$ & $\begin{array}{l}\text { elevation (m a.s.I.) / } \\
\text { nadmorská výška }(\mathrm{m})\end{array}$ \\
\hline Røros & sparse pine forest ${ }^{1}$, bogs and wetlands ${ }^{2}$, flat terrain without cliffs or mountains ${ }^{3}$ & $680-750$ \\
\hline Holtålen & mountain forest $t^{4}$, bogs and wetlands & $630-660$ \\
\hline Meråker & mountain forest and bogs ${ }^{5}$ & $450-500$ \\
\hline Selbu & valley with forest and felled areas ${ }^{6}$, bogs and cultivated pastures ${ }^{7}$ & $220-350$ \\
\hline Stjørdal & cultivated areas ${ }^{8}$, bogs and wetlands & $30-350$ \\
\hline Malvik & forest $^{9}$, river $^{10}$, bogs ${ }^{11}$, cultivated pastures and farmland ${ }^{12}$ & $0-250$ \\
\hline Agdenes & coastal heath ${ }^{13}$, marsh $^{14}$, wetlands ${ }^{15}$, beach $^{16}$, cultivated pastures and farmland & $0-160$ \\
\hline Snillfjord & coastal heath, marsh, wetlands, beach, cultivated pastures and farmland & $0-300$ \\
\hline Flatanger & island in saline ${ }^{17} ;$ coastal heath, marsh, wetlands, beach, cultivated pastures and farmland & $0-170$ \\
\hline Osen & island in saline; coastal heath, marsh, wetlands, beach, cultivated pastures and farmland & $0-160$ \\
\hline Åfjord & island in saline; coastal heath, marsh, wetlands, beach, cultivated pastures and farmland & $0-140$ \\
\hline Ørland & $\begin{array}{l}\text { island in saline and mainland; coastal heath, marsh, wetlands, beach, } \\
\text { cultivated pastures and farmland }\end{array}$ & $0-200$ \\
\hline Hitra & marsh, wetlands, coastal heath, sparse pine forest, farmland ${ }^{18}$, archipelago ${ }^{19}$ & $0-150$ \\
\hline Frøya & island in saline; coastal heath, marsh, wetlands, archipelago, farmland & $0-60$ \\
\hline
\end{tabular}

Habitaty: ${ }^{1}$ riedke borovicové lesy, ${ }^{2}$ rašeliniská a mokrade, ${ }^{3}$ rovinatý terén bez útesov alebo hôr, ${ }^{4}$ horské lesy, ${ }^{5}$ horské lesy a rašeliniská, ${ }^{6}$ lesnaté údolie $\mathrm{s}$ vyt’aženými plochami, ${ }^{7}$ rašeliniská a kultivované pasienky, ${ }^{8}$ kultivované územia, ${ }^{9}$ les, ${ }^{10}$ rieka, ${ }^{11}$ rašeliniská, ${ }^{12}$ kultivované pasienky a pol'nohospodárske plochy, ${ }^{13}$ pobrežné vresoviská, ${ }^{14}$ pobrežné mokrade, ${ }^{15}$ mokrade, ${ }^{16}$ pláž, ${ }^{17}$ morský ostrov, ${ }^{18}$ pol'nohospodárske plochy, ${ }^{19}$ polostrov.

nesting; some nests were also abandoned from the past. In some nest surroundings we also found resting sites with a higher concentration of pellets where we collected pellets as well as bones from the remains of old pellets. In the nests we collected the loose recent bone layer. In cases where bones were located deeper in the hard soil layer we processed this material individually and a bone sample was sent for $\mathrm{C}^{14}$ dating analysis to the Research Laboratory for Archaeology and the History of Art, University of Oxford. The age of the oldest layers is included in the results. Osteological material from nests was separated by washing in a container with water. Organic remains were removed with a 5\% solution of $\mathrm{NaOH}$ and washed under running water. After drying the samples for identification purposes, the jaws of mammals were sorted. Among the Arvicolinae, we included the jaws where the first upper molar $\mathrm{M}_{1}$ had fallen out and among the Leporidae, we included the heel bone calcaneus. Among the birds, we identified the bones of bills: premaxilla and mandibula, wings: $h u$ merus and metacarpus and feet: tarsometatarsus. Among the amphibians we focused on the os ilium, among the fish it was their jawbones, the insects their heads and the crabs their claws. The number of individual species, or taxa, in the samples was determined by the most abundant of their body parts found. The identification of bones was undertaken using the collec- tion of vertebrate skeletons at the Botanical Garden of Comenius University in Blatnica.

In the study we analyse the sums of all samples in individual municipalities without differentiating them by age and location. In the modified tables the samples are sorted by similarities of the species spectra. The order of the species is specified in such a way that the plus values of marked differences from the mean values, calculated using the Chi-quadrate test (+ MDFM, Obuch 2001), are arranged into blocks that are marked in the tables with a bold line. Under the dotted line in the table there are stated more numerous species without a marked difference from the mean arranged by decreasing values of total abundance. In the last line of each table the diversity indices H' are specified, calculated according to Shannon \& Weaver (1949). The least abundant species are given beneath the tables. The MDFM computations and modified tables were generated by the program Zber (Šipöcz 2004).

\section{Results}

The main goal of our research was to acquire comparative material of $B$. bubo food from three parts of Trøndelag: from the mountains (including sparse forest and peatland in highland areas), lower areas close to the sea shore and from islands along the coast. In eight years we collected food remains from 45 sites in 14 
municipalities where we found 76 nests of $B$. bubo with prey remains from various dates.

Die t of $B u b o \quad b u b o$ i n $\mathrm{the}$

$\mathrm{mount}$ a i n s

The basic food components of $B$. bubo in mountainous areas of Trøndelag were mammals (Mammalia, 64.8\%), in particular rodents of the subfamily Arvicolinae: species of Microtus agrestis (27.6\%), Lemmus lemmus (11.6\%), Arvicola amphibius $(8.7 \%)$ and Clethrionomys rufocanus (7.0\%) (Appendix 1). Among birds (Aves, $18.4 \%$ ) the most important food components were the family Phasianidae: Lagopus lagopus (5.9\%) and Lagopus muta (1.1\%), Anatidae: species Anas crecca $(2.9 \%)$ and Scolopacidae. Another significant food component was frogs, species Rana temporaria $(16.6 \%)$.

The highest located nests were found in the municipality of Røros ( 780 meters above sea level), close to the lakes, rivers and peatlands. Here $B$. bubo often hunts for birds, i.e. ducks ( 9 species) and shorebirds (12 species). Of rodents, in addition to prevailing species $M$. agrestis and L. lemmus, also species of Clethrionomys glareolus, Myopus schisticolor and Sciurus vulgaris were well represented.

In the oldest part of the nesting area (650 meters above sea level in highland forest and peatland) in the municipality of Holtålen (up to 150 years old) a rare occurrence of ptarmigan L. muta was found. Unlike the other mountainous areas, here frogs $R$. temporaria and grey-sided vole, $C$. rufocanus were represented more often.

In the valley of Dalåa and Tevla in Meråker municipality, one nest of $B$. bubo contained bones older than 60 years. In another place we found one recent and one subfossil nest, where lower layers were dated back 3960 years. The oldest layers contained mainly water voles $A$. amphibius and lemmings L. lemmus.

In the valley of Neadalen in Selbu municipality, we found an abandoned nest of $B$. bubo with few breeding (small samples) attempts in recent times, the food remains of which were clearly dominated by M. agrestis.

D i e t of $B u b o \quad b u b o \quad \mathrm{c} l o \mathrm{se} t \mathrm{o}$ the continental coast

In 13 samples from 5 municipalities close to the seashore of Trondheimsfjorden, Kråkvågfjorden and Åstfjorden almost half of the prey was mammals (Mammalia, 48.9\%) (Appendix 2). Birds (Aves, 13.0\%) were a less plentiful component of the diet of $B$. bubo here, and frogs of species $R$. temporaria were represented more significantly (37.9\%).

An abandoned nest located about $2.6 \mathrm{~km}$ from the coast in Malvik municipality contained bones in the deepest layer up to 300 years old. In addition to the predominant species of M. agrestis, rodents L. lemmus and A. amphibius were also well represented. Phasianidae and Anatidae were the birds most often hunted.

Two nests in Stjørdal municipality were located further from the coast, one in a wide valley near agricultural areas and one in forest and peatland higher up. In forest and peatland the diet of $B$. bubo consists mostly of mammals, particularly species of $M$. agrestis and $L$. lemmus. Of birds, L. lagopus was most often hunted.

In the municipality of Agdenes, we collected food remains from two territories of $B$. bubo located close to the coast in mountain landscape with peatlands and almost no forest. They consisted mostly of frogs $R$. temporaria $(50.7 \%)$ and a considerable proportion of birds.

From the municipality of Snillfjord we analysed four bone samples from two territories (four nests) close to the end of the fjord and on a small island by the coast: water birds of families Laridae and Alcidae formed a significant part of the prey (Aves, 34.5\%).

There are vast peatlands in the vicinity of inland nests of $B$. bubo in Ørland municipality, where B. bubo hunts mostly frogs and species of water birds.

Diet of $\quad B u b o \quad b u b o$ on the is$1 \mathrm{a} \mathrm{n} \mathrm{d} \mathrm{s}$

On the northern offshore islands rodents were more represented, forming a significant part of the $B$. bubo prey. M. agrestis $(50.5 \%), A$. amphibius $(8.4 \%)$ and $L$. lemmus $(3.5 \%)$ were the species most often hunted (Appendix 3). On the southern islands of Hitra and Frøya water bird species of the family Laridae were an important part of the diet: Larus argentatus $(2.6 \%$ and Larus canus (1.7\%), Anatidae: Anas platyrhynchos $(1.1 \%)$ and $A$. crecca (1.1\%), Alcidae: Fratercula arctica $(1.3 \%)$ and Alle alle $(0.7 \%)$ and other species of Charadriiformes. On some islands frogs were often hunted (R. temporaria, 9.2\%). On the islands with frogs, this species is well represented. Fish and invertebrates were sporadically represented in the diet of $B$. bubo here.

On the island of Halmøya, Flatanger municipality, we found a large number of bones, which were processed in three layers. Their age will be determined in a separate study. The main diet components of $B$. bubo at this site were mammals (Mammalia, 81.8\%). Recently 
the island has gradually been overgrown by woody plants and $M$. agrestis has become dominant (62.6\%). The island had no forests in the past with sheep grazing there. The species of $A$. amphibius was more represented $(14.2 \%)$ in the oldest cultural layer. Birds (Aves, $9.7 \%, 97$ species) were less plentiful but more varied prey components of $B$. bubo. The most plentiful species was $F$. arctica (1.3\%). Recently frogs ( $R$. temporaria, $8,2 \%$ ) have been more often hunted.

On the island of Ramsøya, Osen municipality, $B$. bubo used five sites for nesting in turn, and under an overhanging rock we found a resting site with pellets. The oldest bones were 60-70 years old. M. agrestis $(61.5 \%)$ was dominant among mammals (Mammalia, $77.5 \%$ ), while in samples from some of the nests $L$. lemmus was represented (11.0\%). The occurrence of $L$. lemmus originates from invasions in years with a lot of L. lemmus on the mainland. This applies to the instance of $L$. lemmus on the other islands as well. Under such circumstances $L$. lemmus swim to the islands. In addition, a surprisingly high number of Sorex araneus $(2.1 \%)$ was found. In pellets, frogs were frequent $(R$. temporaria, 6.8\%). Of birds (Aves, 15.1\%, 68 species) the species most frequently hunted was $L$. argentatus $(1.1 \%)$.

On Linesøya in Åfjord municipality we collected samples from two nests in the same territory of B. bubo. Mammals (Mammalia, 68.6\%) were less represented than in the two previous islands with prevailing species of $M$. agrestis $(65.6 \%)$. Also here there was a surprisingly high number of $S$. araneus $(5,1 \%)$. Frogs were most represented in pellets from 2013 (R. temporaria, $14.0 \%$ ). Of birds (Aves, 17.1\%, 58 species) L. argentatus $(1.8 \%)$ and Gallinago gallinago (1.8) were the species most frequently hunted.

On Storfosna in Ørland municipality we collected food remains of $B$. bubo from two nests in the same territory on the cliffs. Rodents of subfamily Arvicolinae were not found there, and therefore mammals (Mammalia, 28.4\%) were most often represented by mouse (Mus musculus, 10.3\%), hare (Lepus timidus, 9.6\%) and hedgehog (Erinaceus europaeus, 7.5\%). Frogs were also missing, so the dominant part of the prey of $B$. bubo was birds (Aves, 70.4\%, 59 species), in particular species L. canus (12.1\%), L. argentatus (6.5\%), Vanellus vanellus (11.1\%) and A. platyrhynchos (5.7\%).

On Hitra the material represented 14 territories and 19 nests of B. bubo. Of mammals (Mammalia, 34.0\%) the most frequent prey species were Clethrionomys glareolus (12.5\%), L. timidus (8.1\%), Rattus norvegicus
(6.1\%) and E. europaeus $(3.5 \%)$. The main prey were birds (Aves, 65.6\%, 81 species), and of these the most frequently represented species were $L$. argentatus $(10.3 \%)$, L. canus $(4.8 \%), F$. arctica $(4.3 \%)$, A. alle (3.9\%), G. gallinago (5.4\%), Scolopax rusticola (3.2\%), A. crecca $(3.2 \%)$ and A. platyrhynchos $(2.6 \%)$. Auks were presented in the owls' diet mainly during periods outside the breeding season. Among gulls the young ones were prevalent, as $B$. bubo hunts them in their nesting colonies.

On Frøya $B$. bubo used 17 nesting sites in ten territories. In its diet mammals (Mammalia, 10.8\%) were mostly represented by species $R$. norvegicus $(3.8 \%), L$. timidus $(2.5 \%)$, E. europaeus (1.6\%) and Neomys fodiens $(1.6 \%)$.

The common frog $R$. temporaria (24.3\%) was introduced to the island of Frøya repeatedly after 1960 (Dolmen \& Seland 2016). Over the past ten years, this frog has become common in several places on this island. In some territories $B$. bubo has started using it as an attractive diet component. L. lagopus $(3.2 \%)$ was an attractive prey in this area. The pheasant Phasianus colchicus $(0.3 \%)$ was introduced earlier, but has probably not expanded enough on the island. The representation of bird species in the diet of B. bubo (Aves, 63.4\%, 81 species) is similar to the situation on Hitra.

Ty p s of $B u b o \quad b u b o$ d i e t i n

T r $ø$ n d e 1 a g

From our present findings from 39 sites in SørTrøndelag county and six sites in Nord-Trøndelag county, it is possible to differentiate the proportional representation of types of prey in the mountains and in the proximity of the coast (Tab. 2). However, the findings from the islands are so varied that we have separated the biggest collections made over a long period on Halmøya, Nord-Trøndelag, from more recent samples acquired on Ramsøya and Linesøya. Here the dominant food components of $B$. bubo are still mammals, subfamily Arvicolinae. On Storfosna, Hitra and Frøya in the southern part of Sør-Trøndelag the B. bubo hunts mostly for birds.

In the mountainous diet type of $B$. bubo in Trøndelag the diagnostic species are rodents, M. oеconomus, $M$. schisticolor and C. rufocanus, and birds, L. muta, Tetrao urogalus, Tringa nebularia, Numenius phaeopus and Turdus torquatus. Bird species of L. lagopus, A. crecca, Bucephala clangula and Philomachus pugnax often appear as the prey of $B$. bubo not only in the mountains but also on the southern islands, e.g. the spe- 
Tab. 2. Comparison of abundance of diagnostic species in five types of Bubo bubo diet in Trøndelag. Numerical values in the table are presented in absolute value; positive and negative deviations $(1+, 2+$, and $1-, 2-)$ are marked differences from the mean (MDFM, Obuch 2001) within a respective species, across locations. Species with plus values of MDFM (1+, 2+) are arranged into blocks marked with a bold line. Under the dotted line are more numerous species without MDFM arranged by decreasing values of total abundance. The diversity index $\mathrm{H}^{\prime}$ is calculated according to the work of Shannon \& Weaver (1949). For more details see Methods.

Tab. 2. Porovnanie početnosti diagnostických druhov $v$ piatich typoch potravy Bubo bubo v regióne Trøndelag. Číselné hodnoty $v$ tabul'ke sú uvedené $v$ absolútnych hodnodnotách, kladné a záporné odchýlky $(1+, 2+$ a 1 -, 2-) sú významné odchýlky od priemeru (MDFM, Obuch 2001 ) v rámci toho istého druhu, naprieč lokalitami. Druhy s pozitívnymi hodnotami MDFM (1+, 2+) sú zoradené do blokov vyznačených plnou čiarou. Pod bodkovanou čiarou sú početnejšie zastúpené druhy bez hodnôt MDFM zoradené zostupne podla ich početnosti. Index diverzity H' je vypočítaný podla práce Shannon \& Weaver (1949). Pre viac informácii pozri Metodiku.

\begin{tabular}{|c|c|c|c|c|c|c|c|c|c|c|c|c|}
\hline \multirow{2}{*}{$\begin{array}{l}\text { region / územie } \\
\text { taxa / taxón }\end{array}$} & \multirow{2}{*}{\multicolumn{2}{|c|}{$\begin{array}{l}\text { mountains / } \\
\text { hory }\end{array}$}} & \multirow{2}{*}{\multicolumn{2}{|c|}{$\begin{array}{l}\text { coast / } \\
\text { pobrežie }\end{array}$}} & \multicolumn{2}{|c|}{ Halmøya } & \multirow{2}{*}{\multicolumn{2}{|c|}{$\begin{array}{l}\text { Linesoya } \\
\text { Ramsoya }\end{array}$}} & \multicolumn{4}{|c|}{$\begin{array}{l}\text { Frøya } \\
\text { Hitra }\end{array}$} \\
\hline & & & & & & & & & Sto & sna & $\Sigma$ & $\%$ \\
\hline Microtus oeconomus & $3+$ & 241 & $3-$ & 5 & $5-$ & 0 & 4- & 0 & $3-$ & 0 & 246 & 0.60 \\
\hline Myopus schisticolor & $2+$ & 25 & $1-$ & 0 & $2-$ & 0 & & & & & 25 & 0.06 \\
\hline Clethrionomys rufocanus & $2+$ & 477 & & 190 & 4- & 19 & $2-$ & 35 & $5-$ & 0 & 721 & 1.77 \\
\hline Lagopus muta & $2+$ & 75 & $2-$ & 5 & $2-$ & 10 & $1-$ & 6 & $2-$ & 0 & 96 & 0.24 \\
\hline Numenius phaeopus & $2+$ & 35 & & 9 & $1-$ & 12 & $1-$ & 1 & & 9 & 66 & 0.16 \\
\hline Surnia ulula & $2+$ & 25 & & 3 & $2-$ & 0 & & & & 1 & 29 & 0.07 \\
\hline Tringa nebularia & $2+$ & 18 & & 3 & $1-$ & 0 & & 1 & & & 22 & 0.05 \\
\hline Aythya fuligula & $2+$ & 19 & & 2 & $1-$ & 2 & & & & 1 & 24 & 0.06 \\
\hline Mustela erminea & $1+$ & 32 & & 22 & & 39 & $1-$ & 6 & $1-$ & 3 & 102 & 0.25 \\
\hline Tetrao urogallus & $1+$ & 16 & & 11 & $2-$ & 0 & & 1 & & 1 & 29 & 0.07 \\
\hline Asio flammeus & $1+$ & 36 & & 34 & $1-$ & 35 & & 27 & & 18 & 150 & 0.37 \\
\hline Turdus torquatus & $1+$ & 8 & & 1 & $1-$ & 0 & & 2 & & 3 & 14 & 0.03 \\
\hline Lagopus lagopus & $2+$ & 397 & $1-$ & 86 & $2-$ & 83 & $1-$ & 43 & $1+$ & 132 & 741 & 1.82 \\
\hline Anas crecca & $1+$ & 196 & $1-$ & 78 & $1-$ & 80 & $2-$ & 25 & $1+$ & 157 & 536 & 1.31 \\
\hline Philomachus pugnax & $1+$ & 27 & & 17 & $1-$ & 12 & $1-$ & 4 & $1+$ & 32 & 92 & 0.23 \\
\hline Bucephala clangula & $1+$ & 28 & $1-$ & 9 & $2-$ & 3 & $1-$ & 2 & $2+$ & 33 & 75 & 0.18 \\
\hline Clethrionomys glareolus & $1+$ & 245 & $1+$ & 287 & $2-$ & 86 & $4-$ & 7 & $1+$ & 256 & 881 & 2.16 \\
\hline Lemmus lemmus & $1+$ & 784 & $1+$ & 827 & $1-$ & 513 & & 365 & 6- & 1 & 2490 & 6.11 \\
\hline Mustela nivalis & $1+$ & 26 & $1+$ & 22 & $1-$ & 12 & $1-$ & 2 & & 6 & 68 & 0.17 \\
\hline Aegolius funereus & $1+$ & 14 & $1+$ & 19 & $1-$ & 3 & $1-$ & 0 & $1-$ & 0 & 36 & 0.09 \\
\hline Sciurus vulgaris & & 21 & $2+$ & 80 & $3-$ & 1 & $2-$ & 0 & $2-$ & 0 & 102 & 0.25 \\
\hline Tetrastes bonasia & & 7 & $2+$ & 25 & $2-$ & 0 & $1-$ & 0 & & & 32 & 0.08 \\
\hline Lyrurus tetrix & & 31 & $1+$ & 76 & $1-$ & 47 & & 36 & & 22 & 212 & 0.52 \\
\hline Vulpes vulpes & & 1 & $1+$ & 6 & & & & & & & 7 & 0.02 \\
\hline Rana temporaria & & 1127 & $1+$ & 3410 & $1-$ & 1183 & $1-$ & 552 & $1-$ & 555 & 6827 & 16.75 \\
\hline Columba palumbus & $1-$ & 1 & $1+$ & 15 & $2-$ & 2 & $1+$ & 13 & & 8 & 39 & 0.10 \\
\hline Arvicola amphibius & $1+$ & 587 & $2-$ & 223 & $1+$ & 2059 & 6- & 7 & 3- & 38 & 2914 & 7.15 \\
\hline Aythya marila & & & & & $1+$ & 12 & & & & & 12 & 0.03 \\
\hline Somateria mollissima & $2-$ & 0 & $1-$ & 2 & $1+$ & 25 & & 4 & $1+$ & 18 & 49 & 0.12 \\
\hline Mergus merganser & $2-$ & 0 & $2-$ & 2 & $1+$ & 38 & & 6 & $1+$ & 13 & 59 & 0.14 \\
\hline Uria aalge & - & 0 & $1-$ & 1 & $1+$ & 29 & & 4 & $1+$ & 12 & 46 & 0.11 \\
\hline Fratercula arctica & 4- & 0 & $2-$ & 18 & $1+$ & 189 & $1-$ & 16 & $2+$ & 112 & 335 & 0.82 \\
\hline Calidris maritima & $2-$ & 0 & $2-$ & 1 & $1+$ & 38 & $1+$ & 21 & $1-$ & 1 & 61 & 0.15 \\
\hline Microtus agrestis & $1-$ & 1871 & $1-$ & 2468 & $1+$ & 9073 & $1+$ & 3546 & 8- & 8 & 16,966 & 41.62 \\
\hline Sorex araneus & $2-$ & 8 & $2-$ & 9 & $1-$ & 37 & $2+$ & 125 & 3- & 0 & 179 & 0.44 \\
\hline Calidris alpina & & 5 & $2-$ & 0 & & 10 & $2+$ & 22 & & 1 & 38 & 0.09 \\
\hline Tringa totanus & & 7 & $1-$ & 0 & $2-$ & 0 & $1+$ & 10 & & 7 & 24 & 0.06 \\
\hline Cepphus grylle & $1-$ & 0 & $1-$ & 0 & & 14 & $1+$ & 12 & & 7 & 33 & 0.08 \\
\hline Asio otus & & 6 & & 8 & $2-$ & 1 & $1+$ & 15 & & 3 & 33 & 0.08 \\
\hline Turdus iliacus & & 9 & & 14 & $1-$ & 11 & $1+$ & 26 & & 12 & 72 & 0.18 \\
\hline Turdus pilaris & & 25 & & 48 & $2-$ & 16 & $1+$ & 38 & $1+$ & 54 & 181 & 0.44 \\
\hline Alle alle & 4- & 0 & $1-$ & 27 & $2-$ & 13 & $1+$ & 47 & $2+$ & 113 & 200 & 0.49 \\
\hline Charadrius hiaticula & $1-$ & 0 & $1-$ & 3 & $1-$ & 5 & $1+$ & 13 & $2+$ & 20 & 41 & 0.10 \\
\hline Erinaceus europaeus & $3-$ & 0 & $1-$ & 20 & 4- & 0 & $3-$ & 0 & $3+$ & 152 & 172 & 0.42 \\
\hline Rattus norvegicus & $2-$ & 7 & & 76 & $5-$ & 0 & $4-$ & 0 & $3+$ & 209 & 292 & 0.72 \\
\hline Larus argentatus & $5-$ & 0 & $2-$ & 36 & 4- & 19 & & 77 & $3+$ & 552 & 684 & 1.68 \\
\hline
\end{tabular}


Tab. 2. Continuation.

Tab. 2. Pokračovanie.

\begin{tabular}{|c|c|c|c|c|c|c|c|}
\hline \multirow{2}{*}{$\begin{array}{l}\text { region / územie } \\
\text { taxa / taxón }\end{array}$} & \multirow[t]{2}{*}{$\begin{array}{l}\text { mountains / } \\
\text { hory }\end{array}$} & \multirow[t]{2}{*}{$\begin{array}{l}\text { coast / } \\
\text { pobrežie }\end{array}$} & \multirow[t]{2}{*}{ Halmøya } & \multirow[t]{2}{*}{$\begin{array}{l}\text { Linesoya } \\
\text { Ramsoya }\end{array}$} & \multirow{2}{*}{$\begin{array}{l}\text { Frøya } \\
\text { Hitra } \\
\text { Storfosna } \\
\end{array}$} & \multirow{3}{*}{$\frac{\sum}{474}$} & \multirow{3}{*}{$\frac{\%}{1.16}$} \\
\hline & & & & & & & \\
\hline Larus canus & 10 & $2-$ & $2-$ & 29 & 332 & & \\
\hline Larus marinus & 2- & 3- & 3- & 13 & $3+$ & 95 & 0.23 \\
\hline Lepus timidus & 68 & 127 & $5-$ & 37 & 277 & 511 & 1.25 \\
\hline Neomys fodiens & 1- & 1- & $2-$ & $1-$ & $2+$ & 40 & 0.10 \\
\hline Mus musculus & $2-$ & 30 & 3- & 21 & $2+$ & 116 & 0.28 \\
\hline Neovison vison & 1 & 1 & $1-$ & 1 & $2+$ & 21 & 0.05 \\
\hline Ardea cinerea & & 1 & $1-$ & 5 & $2+$ & 22 & 0.05 \\
\hline Anas platyrhynchos & 55 & 72 & 3- & 34 & 218 & 400 & 0.98 \\
\hline Anas penelope & 11 & $2-$ & $1-$ & $1-$ & $2+$ & 76 & 0.19 \\
\hline Mergus serrator & $1-$ & $2-$ & $1-$ & $1-$ & $2+$ & 82 & 0.20 \\
\hline Haematopus ostralegus & 3- & $1-$ & 61 & 17 & $2+$ & 150 & 0.37 \\
\hline Pluvialis apricaria & 20 & 31 & $1-$ & 19 & $2+$ & 178 & 0.44 \\
\hline Vanellus vanellus & $2-$ & 36 & $2-$ & 11 & 110 & 182 & 0.45 \\
\hline Numenius arquata & $2-$ & $2-$ & $2-$ & 13 & $2+$ & 71 & 0.17 \\
\hline Scolopax rusticola & $2-$ & $1-$ & $2-$ & 25 & $2+$ & 151 & 0.37 \\
\hline Gallinago gallinago & 26 & $1-$ & $2-$ & 67 & 205 & 431 & 1.60 \\
\hline Turdus merula & 1- & 14 & $1-$ & 14 & $2+$ & 73 & 0.18 \\
\hline Carduelis flavirostris & $1-$ & 1- & $2-$ & 5 & $2+$ & 30 & 0.07 \\
\hline Corvus cornix & 15 & 75 & $1-$ & 32 & 112 & 318 & 0.78 \\
\hline Corvus corax & 1- & 11 & 1- & 12 & $1+$ & 60 & 0.15 \\
\hline Pica pica & 1 & 8 & 1- & 3 & $1+$ & 24 & 0.06 \\
\hline Garrulus glandarius & 1 & 6 & $1-$ & 1 & $1+$ & 18 & 0.04 \\
\hline Sturnus vulgaris & 1- & 6 & 14 & 5 & $1+$ & 47 & 0.12 \\
\hline Turdus philomelos & 9 & 16 & $1-$ & 16 & $1+$ & 83 & 0.20 \\
\hline Melanitta fusca & 1 & 2 & 8 & & $1+$ & 24 & 0.06 \\
\hline Anas acuta & 5 & 4 & $1-$ & 1 & $1+$ & 22 & 0.05 \\
\hline Phasianus colchicus & & 2 & & & $1+$ & 8 & 0.02 \\
\hline Limosa limosa & 1 & & 1- & 1 & $1+$ & 12 & 0.03 \\
\hline Limosa lapponica & $1-$ & $1-$ & 17 & $1-$ & $1+$ & 32 & 0.08 \\
\hline Larus fuscus & & 4 & 1- & & $1+$ & 12 & 0.03 \\
\hline Rissa tridactyla & $1-$ & 5 & 9 & 8 & $1+$ & 32 & 0.08 \\
\hline Sterna hirundo & & & 1 & 2 & $1+$ & 14 & 0.03 \\
\hline Sterna paradisaea & 1 & 1- & 7 & 7 & $1+$ & 29 & 0.07 \\
\hline Bubo bubo & 6 & 5 & 18 & $1-$ & $1+$ & 41 & 0.10 \\
\hline Sorex minutus & & 1 & 2 & 2 & $1+$ & 13 & 0.03 \\
\hline Pisces & 1- & $2-$ & 44 & 20 & $1+$ & 110 & 0.27 \\
\hline Uria lomvia & & $1-$ & 12 & 2 & 7 & 21 & 0.05 \\
\hline Lymnocryptes minimus & & 6 & $1-$ & 2 & 4 & 12 & 0.03 \\
\hline Actitis hypoleucos & 1 & 6 & $1-$ & 3 & 5 & 15 & 0.04 \\
\hline Falco tinnunculus & 4 & 2 & 7 & 5 & 3 & 21 & 0.05 \\
\hline Mammalia & 4397 & 1- 4397 & $1+11,846$ & 4135 & 1102 & 25,877 & 63.48 \\
\hline Aves & 1250 & 1165 & 1411 & 897 & $2+\quad 3192$ & 7915 & 19.42 \\
\hline Amphibia, Pisces & 1136 & $1+3423$ & 1227 & 572 & 597 & 6955 & 17.60 \\
\hline Invertebrata & 1 & 2 & 1- & 6 & $1+$ & 19 & 0.05 \\
\hline $\bar{\Sigma}$ & 6784 & 8987 & 14,485 & 5610 & 4900 & 40,766 & 100.00 \\
\hline $\mathbf{H}^{\prime}$ & 2.55 & 2.22 & 1.58 & 1.80 & 3.57 & 2.50 & \\
\hline
\end{tabular}

cies $C$. glareolus on Hitra. The species A. amphibius was represented in old samples from Meråker municipality and from the island of Halmøya. In the mountains and along the coast the species of L. lemmus, Mustela nivalis and Aegolius funereus were more often represented.
The diet type of $B$. bubo at lower altitudes close to the coast includes a great proportion of frogs $R$. temporaria, and a higher comparative representation of forest species of Sciurus vulgaris, Tetrastes bonasia and Lyrurus tetrix is characteristic. 
The collection of samples from the B. bubo nest on Halmøya is distinguished by significant dominance of species $M$. agrestis and A. amphibius. Similarly, as on the southern islands, also here we found higher abundance of water bird species: F. arctica, Uria aalge, Somateria molissima and Mergus merganser.

On Ramsøya and Linesøya, in addition to dominant representation of the species $M$. agrestis in food samples of $B$. bubo, we found a higher abundance of the shrew Sorex araneus and birds: Calidris alpina, Tringa totanus, Cepphus grylle, Asio otus and Turdus iliacus. The birds Turdus pilaris, A. alle and Charadrius hiaticula are more often represented also on the southern islands.

On the southern islands of Frøya, Hitra and Storfosna mammals are a less significant part of the diet of B. bubo (Mammalia, 22.5\%), while more often represented are species of $E$. europaeus, $R$. norvegicus, $L$. timidus, M. musculus, Neovison vison and Neomys fodiens. The most frequently hunted are birds (Aves, $65.1 \%$ ), of which the highest represented are species from the orders of Charadriiformes and Anseriformes.

\section{Discussion}

According to the Norway Bird Distribution Atlas (Solem 1994) and population estimates for Norwegian breeding birds, most of the confirmed occurrences of $B$. bubo are located along the sea coast. The results from the years 2008 to 2012 (Øien et al. 2014) estimate the population in Norway from 451 (minimum) to 681 (maximum) pairs, the highest number of pairs being on the western coast of Rogaland and Hordaland counties. A numerous population is also present on the islands in the north, in the county of Nordland. Half of the 30 to 50 sites of $B$. bubo in Sør-Trøndelag county are on islands, where the significant food components are species of water birds. Similarly, a high proportion of birds (Aves, 63.2\%) in the diet of B. bubo was presented by Willgohs (1974), who acquired most of the material from the western coast of Norway. Hagen (1952) studied the diet of $B$. bubo mainly in the south-east of Norway, in Hedmark county, and in his results mammals are prevalent (Mammalia, $63.3 \%$ ) as they are in our results from the mountainous areas. Both authors present lower representation of frog R. temporaria $(2.8 \%$, or $9.3 \%)$ than we do in our study $(16.8 \%)$. A high proportion of frogs has been found at some sites in Malvik and Agdenes municipalities. The species $R$. temporaria was intensively hunted after its introduction to the island of Frøya. This shows its attractiveness as food for $B$. bubo. Frogs in the diet of $B$. bubo are equally plentiful in the mountainous areas of Slovakia (Obuch \& Karaska 2010).

In their study of the diet of $B$. bubo in southern Kirghizia, the authors Obuch \& Rybin (1993) concluded that its natural environments are in the steppe zone. In the conditions of Central Europe it hunts in cultivated landscapes, which means that forest species of mammals and birds are rare in its diet. Norwegian offshore islands have been deforested by people and grazed by sheep, so the potential prey of $B$. bubo has been enriched also with introduced mammal species: $R$. temporaria, $M$. musculus, $R$. norvegicus, $N$. vison and birds: Columba livia domestica, Gallus gallus domesticus, Phasianus colchicus. Nevertheless, a substantial portion of its diet still consists of original species of birds and mammals despite human activities. After grazing stopped and the areas became overgrown with deciduous forest, as for instance on Halmøya, B. bubo did not necessarily leave the areas; it only changed its diet composition. Similar decrease in agricultural activities can be seen in the highland areas of Trøndelag where deforested areas are being overgrown with thin woods. Here $B$. bubo has adapted to hunting various forest species of mammals, S. vulgaris, M. schisticolor and birds of the family Phasianidae: T. bonasia, $T$. urogalus and Strigidae: S. ulula, A. funereus. B. bubo has in the long period lived in such regions with boreal steppe, even without humans, which is documented by the age of bones from the deep layer of the nest in Meråker municipality They date back to almost 4000 years ago (radiocarbon analysis at the University of Oxford, Oct. 2015).

\section{References}

Domen D \& Seland J 2016: How fast do amphibians disperse? Introductions, distribution and dispersal of the common frog (Rana temporaria) and the common toad (Bufo bufo) on a coastal island in Central Norway. Fauna Norvegica 36: 33-46. DOI: 10.5324/fn.v36i0.1965.

Emmet RE, Mikkola H, Mummery L \& Westerhof G 1972: Prey found in Eagle Owl's nest in central Sweden. British Birds 65: 482-483.

Hagen Y 1952: Hubroen Bubo bubo L.: 351-377. In Hagen Y: Rovfuglene og viltpleien [Birds of prey and game management]. Gyldendal, Oslo, 603.[In Norwegian]

Höglund NH 1966: Über die Ernährung des Uhus Bubo 
bubo Lin. in Schweden während der Brutzeit. Viltrevy 4(2): 43-80.

Obuch J 2001: Using marked differences from the mean (MDFM) method for evaluation of contingency tables. Buteo 12: 37-46.

Obuch J \& Karaska D 2010: The Eurasian eagle-owl (Bubo bubo) diet in the Orava Region (N Slovakia). Slovak Raptor Journal 4: 83-98. DOI: 10.2478/v10262-012-0048-9.

Obuch J \& Rybin SN 1993: Food of the eagle owl (Bubo bubo zaissanensis Chachlov) in southern Kirghizia (Osh District). Folia Zoologica 42: 19-31.

Øien IJ, Heggøy O, Shimmings P, Aarvak T, Jacobsen K-O, Oddane B, Ranke PS \& Steen OF 2014: Status for hubro i Norge [Status of eagle owl in Norway]. Norwegian Ornithological Society. Report 8-2014, 71. [In Norwegian]

Olsson V 1979: Studies on a population of Eagle Owls, Bubo bubo (L.) in Southeast Sweden. Viltrevy 11: 1-99.

Regnell S 1957: Berguv [Eagle owl]. Sveriges Natur 48: 79-90. [In Swedish]
Schaefer H 1970: Womit ernährt der Uhu (Bubo bubo) in Lapland seine Jungen? Bonner Zoologische Beiträge 21: 52-62.

Shannon CE \& Weaver W 1949: The mathematical theory of communication. University of Illinois Press, Urbana, 125.

Šipöcz T 2004: Zber. Databázový program, Verzia 3. [Collection. Database program. Version 3]. Botanical Garden, Comenius University, Blatnica. [In Slovak]

Solheim R 1994: Hubro Bubo bubo [Eagle-owl Bubo bubo], 270-271. In: Gjershaug JO, Thingstad PG, Eldøy S \& Byrkjeland S: Norsk fugleatlas. Hekkefuglenes utbredelse og bestandsstatus i Norge [Norwegian bird atlas. Nesting birds' distribution and population status in Norway]. Norsk Ornitologisk Forening, Klæbu, 551. [In Norwegian]

Willgohs JF 1974: The Eagle owl Bubo bubo (L.) in Norway. Part I. Food ecology. Sterna, Norsk Ornithologisk Forening og Stavanger Museum. Stavanger 13(3): 129-177. 


\section{Appendix 1.}

Diet of Bubo bubo in the mountains. Numerical values in the table are presented in absolute value; positive and negative deviations $(1+, 2+$, and $1-, 2-)$ are marked differences from the mean (MDFM, Obuch 2001) within a respective species, across locations. Species with plus values of MDFM $(1+, 2+)$ are arranged into blocks marked with a bold line. Under the dotted line are more numerous species without MDFM arranged by decreasing values of total abundance. The least abundant prey species are given beneath the table. The diversity index H' is calculated according to the work of Shannon \& Weaver (1949). For more details see Methods.

Vzorky potravy Bubo bubo z hôr. Číselné hodnoty v tabul'ke sú uvedené v absolútnych hodnodnotách, kladné a záporné odchýlky (1 +, 2+ a 1 -, 2-) sú významné odchýlky od priemeru (MDFM, Obuch 2001 ) v rámci toho istého druhu, naprieč lokalitami. Druhy s pozitívnymi hodnotami MDFM $(1+, 2+)$ sú zoradené do blokov vyznačených plnou čiarou. Pod bodkovanou čiarou sú početnejšie zastúpené druhy bez hodnôt MDFM zoradené zostupne podla ich početnosti. Najmenej početné druhy koristi sú pod tabul'kou. Index diverzity H' je vypočítaný podla práce Shannon \& Weaver (1949). Pre viac informácii pozri Metodiku.

\begin{tabular}{|c|c|c|c|c|c|c|c|c|c|c|}
\hline \multirow{2}{*}{$\begin{array}{l}\text { municipality / okres } \\
\text { taxa / taxón } \\
\text { Anas crecca }\end{array}$} & \multicolumn{2}{|c|}{ Røros } & \multicolumn{2}{|c|}{ Holtålen } & \multicolumn{2}{|c|}{ Meråker } & \multicolumn{2}{|c|}{ Selbu } & \multirow{2}{*}{$\begin{array}{c}\sum \\
196\end{array}$} & \multirow{2}{*}{$\begin{array}{c}\% \\
2.89\end{array}$} \\
\hline & $2+$ & 134 & $2-$ & 22 & $1-$ & 38 & $1-$ & 2 & & \\
\hline Anas platyrhynchos & $2+$ & 37 & $1-$ & 6 & $1-$ & 11 & & 1 & 55 & 0.81 \\
\hline Myopus schisticolor & $2+$ & 25 & $2-$ & 0 & $2-$ & 0 & & & 25 & 0.37 \\
\hline Clethrionomys glareolus & $1+$ & 136 & $1-$ & 51 & $1-$ & 53 & $1-$ & 5 & 245 & 3.61 \\
\hline Sciurus vulgaris & $1+$ & 14 & $1-$ & 2 & & 5 & & & 21 & 0.31 \\
\hline Anas penelope & $1+$ & 8 & & & & 3 & & & 11 & 0.16 \\
\hline Aythya fuligula & $1+$ & 14 & & 3 & $1-$ & 1 & & 1 & 19 & 0.28 \\
\hline Mergus serrator & $1+$ & 6 & & & & & & & 6 & 0.09 \\
\hline Tringa nebularia & $1+$ & 15 & $1-$ & 0 & & 3 & & & 18 & 0.27 \\
\hline Numenius phaeopus & $1+$ & 26 & $1-$ & 4 & $1-$ & 5 & & & 35 & 0.52 \\
\hline Gallinago gallinago & $1+$ & 14 & & 5 & $1-$ & 5 & & 2 & 26 & 0.38 \\
\hline Larus canus & $1+$ & 9 & & 1 & $1-$ & 0 & & & 10 & 0.15 \\
\hline Corvus cornix & $1+$ & 10 & & 2 & & 3 & & & 15 & 0.22 \\
\hline Lagopus lagopus & $1+$ & 135 & & 143 & $1-$ & 118 & $2-$ & 1 & 397 & 5.85 \\
\hline Lagopus muta & $1+$ & 26 & $1+$ & 41 & $2-$ & 6 & & 2 & 75 & 1.11 \\
\hline Clethrionomys rufocanus & & 105 & $1+$ & 210 & $1-$ & 146 & & 16 & 477 & 7.30 \\
\hline Lemmus lemmus & & 149 & $1+$ & 321 & & 291 & $1-$ & 23 & 784 & 11.56 \\
\hline Rana temporaria & $1-$ & 135 & $1+$ & 512 & & 462 & $1-$ & 18 & 1127 & 16.61 \\
\hline Turdus pilaris & & 6 & $1+$ & 15 & $1-$ & 3 & & 1 & 25 & 0.37 \\
\hline Turdus torquatus & & & $1+$ & 8 & & & & & 8 & 0.12 \\
\hline Arvicola amphibius & $1-$ & 67 & $2-$ & 38 & $1+$ & 482 & 3- & 0 & 587 & 8.65 \\
\hline Mustela erminea & & 6 & $1-$ & 3 & $1+$ & 22 & & 1 & 32 & 0.47 \\
\hline Microtus agrestis & $1-$ & 203 & & 654 & & 813 & $1+$ & 201 & 1871 & 27.58 \\
\hline Lepus timidus & & 20 & $1-$ & 15 & & 28 & & 5 & 68 & 1.00 \\
\hline Bucephala clangula & & 8 & $1-$ & 4 & & 14 & & 2 & 28 & 0.41 \\
\hline Lyrurus tetrix & & 7 & $1-$ & 5 & & 18 & & 1 & 31 & 0.46 \\
\hline Tetrao urogallus & & 6 & & 8 & $1-$ & 2 & & & 16 & 0.24 \\
\hline Microtus oeconomus & & 58 & & 99 & & 80 & $1-$ & 4 & 241 & 3.55 \\
\hline Asio flammeus & & 11 & & 7 & & 17 & & 1 & 36 & 0.53 \\
\hline Philomachus pugnax & & 3 & & 12 & & 10 & & 2 & 27 & 0.40 \\
\hline Mustela nivalis & & 8 & & 6 & & 12 & & & 26 & 0.38 \\
\hline Surnia ulula & & 5 & & 7 & & 13 & & & 25 & 0.37 \\
\hline Pluvialis apricaria & & 3 & & 11 & & 5 & & 1 & 20 & 0.29 \\
\hline Aegolius funereus & & 2 & & 1 & & 9 & & 2 & 14 & 0.21 \\
\hline Turdus iliacus & & 1 & & 6 & & 2 & & & 9 & 0.13 \\
\hline Turdus philomelos & & 2 & & 2 & & 5 & & & 9 & 0.13 \\
\hline Sorex araneus & & 3 & & 3 & & 2 & & & 8 & 0.12 \\
\hline Rattus norvegicus & & & & 2 & & 5 & & & 7 & 0.10 \\
\hline Tetrastes bonasia & & 1 & & & & 6 & & & 7 & 0.10 \\
\hline Tringa totanus & & 2 & & 2 & & 3 & & & 7 & 0.10 \\
\hline Tringa glareola & & 3 & & 3 & & & & & 6 & 0.09 \\
\hline Bubo bubo & & 3 & & 1 & & 1 & & 1 & 6 & 0.09 \\
\hline Asio otus & & 2 & & 2 & & 2 & & & 6 & 0.09 \\
\hline Mammalia & 1- & 794 & & 1404 & & 1944 & $1+$ & 255 & 4397 & 64.81 \\
\hline Aves & $1+$ & 546 & & 349 & $1-$ & 333 & 1- & 22 & 1250 & 18.43 \\
\hline Amphibia, Pisces & $1-$ & 140 & $1+$ & 515 & & 462 & $1-$ & 19 & 1136 & 16.75 \\
\hline Invertebrata & & 1 & & 0 & & 0 & & 0 & 1 & 0.01 \\
\hline $\bar{\Sigma}$ & & 1481 & & 2268 & & 2739 & & 296 & 6784 & 100.00 \\
\hline $\mathbf{H}^{\prime}$ & & 3.3 & & 2.26 & & 2.28 & & 1.42 & 2.55 & \\
\hline
\end{tabular}


Slovak Raptor Journal 2016, 10: 51-64. DOI: 10.1515/srj-2016-0005.

(C) Raptor Protection of Slovakia (RPS)

\section{Appendix 1.}

Continuation.

Pokračovanie.

Other species (municipality-number) / ostatné druhy (okres-počet): Mus musculus (3-1), Castor fiber (3-1), Vulpes vulpes (3-1), Alopex lagopus (3-1), Neovison vison (3-1), Podiceps auritus (3-1), Anas querquedula (1-3; 3-1), Anas acuta (1-5), Melanitta fusca (1-1), Anatidae (1-5; 2-1), Accipiter gentilis (1-1; 3-1), Buteo lagopus (1-1; 2-2; 3-1), Pandion haliaetus (1-1), Falco tinnunculus (1-1; 2-1; 3-2), Falco columbarius (1-2; 2-2; $3-1)$, Gallus gallus dom. (3-1), Vanellus vanellus (1-3; 2-2), Calidris alpina (1-1; 2-3; 4-1), Calidris temminckii (2-1), Calidris canutus (2-1), Actitis hypoleucos (1-1), Limosa limosa (3-1), Scolopax rusticola (1-1; 2-3; 3-1), Gallinago media (1-2; 3-1), Larus ridibundus (1-1), Sterna paradisaea (1-1), Columba palumbus (3-1), Cuculus canorus (2-1; 3-2), Anthus pratensis (2-1), Lanius excubitor (1-1), Sylvia curruca (1-1), Oenanthe oenanthe (1-1), Turdus merula (2-1; 3-1), Turdus viscivorus (2-2), Plectrophenax nivalis (2-1), Fringilla montifringilla (1-1; 3-1), Fringilla coelebs (1-1; 3-3), Carduelis flammea (3-1), Pinicola enucleator (3-1), Loxia curvirostra (3-1), Sturnus vulgaris (3-1), Garrulus glandarius (4-1), Perisoreus infaustus (1-3; 3-1), Pica pica (1-1), Corvus corax (1-1; 2-1; 3-1), Passeriformes (3-2), Aves juv. (1-7; 2-5; 3-3), Salmonidae (2-3), Esox lucius (1-1), Pisces $(1-4 ; 4-1)$, Coleoptera (1-1)

\section{Appendix 2.}

Diet of Bubo bubo close to the continental sea coast. See Appendix 1 for more details.

Vzorky potravy Bubo bubo z blízkosti pevninského pobrežia. Pre viac inforácií vid’ Appendix 1.

\begin{tabular}{|c|c|c|c|c|c|c|c|c|c|c|c|c|}
\hline \multirow{2}{*}{$\begin{array}{l}\text { municipality / okres } \\
\text { taxa / taxón } \\
\text { Arvicola amphibius }\end{array}$} & \multicolumn{2}{|c|}{ Malvik } & \multicolumn{2}{|c|}{ Stjordal } & \multicolumn{2}{|c|}{ Agdenes } & \multicolumn{2}{|c|}{ Snillfjord } & \multicolumn{2}{|c|}{ Ørland } & \multirow{2}{*}{$\begin{array}{l}\Sigma \\
223\end{array}$} & \multirow{2}{*}{\begin{tabular}{|c|}
$\%$ \\
2.48
\end{tabular}} \\
\hline & $1+$ & 201 & $2-$ & 10 & 4- & 0 & $2-$ & 2 & & 10 & & \\
\hline Rattus norvegicus & $1+$ & 72 & $2-$ & 2 & $3-$ & 0 & $1-$ & 0 & & 2 & 76 & 0.85 \\
\hline Mus cf. musculus & $1+$ & 24 & $1-$ & 0 & $1-$ & 1 & & & & 5 & 30 & 0.33 \\
\hline Sciurus vulgaris & $1+$ & 72 & $1-$ & 6 & $2-$ & 2 & $1-$ & 0 & & & 80 & 0.89 \\
\hline Tetrastes bonasia & $1+$ & 21 & $1-$ & 0 & & 2 & & 1 & & 1 & 25 & 0.28 \\
\hline Asio flammeus & $1+$ & 24 & $1-$ & 2 & & 3 & & 2 & & 3 & 34 & 0.38 \\
\hline Aegolius funereus & $1+$ & 16 & & 1 & & 1 & & 1 & & & 19 & 0.21 \\
\hline Lemmus lemmus & $1+$ & 560 & $1+$ & 262 & $6-$ & 1 & $4-$ & 3 & $3-$ & 1 & 827 & 9.20 \\
\hline Microtus agrestis & & 1093 & $1+$ & 748 & $1-$ & 438 & $1-$ & 155 & $1-$ & 34 & 2468 & 27.46 \\
\hline Lagopus lagopus & $1-$ & 16 & $1+$ & 27 & $1+$ & 28 & $1+$ & 14 & & 1 & 86 & 0.96 \\
\hline Rana temporaria & & 1534 & & 596 & $1+$ & 997 & $1-$ & 179 & & 104 & 3410 & 37.94 \\
\hline Lepus timidus & & 47 & $1-$ & 8 & $1+$ & 55 & & 12 & & 5 & 127 & 1.41 \\
\hline Vulpes vulpes & & & & & $1+$ & 6 & & & & & 6 & 0.07 \\
\hline Vanellus vanellus & & 11 & & 3 & $1+$ & 14 & & 4 & & 4 & 36 & 0.40 \\
\hline Columba palumbus & $1-$ & 1 & & 2 & $1+$ & 9 & & 2 & & 1 & 15 & 0.17 \\
\hline Turdus pilaris & $1-$ & 9 & & 5 & $1+$ & 26 & & 5 & & 3 & 48 & 0.53 \\
\hline Anas crecca & $1-$ & 19 & $1-$ & 6 & $1+$ & 39 & & 5 & $1+$ & 9 & 78 & 0.87 \\
\hline Gallinago gallinago & $2-$ & 11 & $1-$ & 4 & $1+$ & 43 & $1+$ & 11 & & 5 & 74 & 0.82 \\
\hline Clethrionomys rufocanus & $2-$ & 19 & $1-$ & 26 & $1+$ & 65 & $2+$ & 78 & & 2 & 190 & 2.11 \\
\hline Haematopus ostralegus & $1-$ & 2 & & 2 & & 5 & $1+$ & 7 & & 2 & 18 & 0.20 \\
\hline Larus argentatus & 3- & 0 & $1-$ & 0 & & 4 & $3+$ & 31 & & 1 & 36 & 0.40 \\
\hline Larus canus & $2-$ & 3 & $1-$ & 2 & & 11 & $2+$ & 22 & & 1 & 39 & 0.43 \\
\hline Fratercula arctica & $2-$ & 0 & & & & 1 & $2+$ & 17 & & & 18 & 0.20 \\
\hline Alle alle & $2-$ & 0 & $1-$ & 0 & $1-$ & 1 & $2+$ & 26 & & & 27 & 0.30 \\
\hline Corvus cornix & & 37 & $1-$ & 6 & $1-$ & 9 & $1+$ & 20 & & 3 & 75 & 0.83 \\
\hline Erinaceus europaeus & & 5 & & 3 & $1-$ & 0 & & 1 & $2+$ & 11 & 20 & 0.22 \\
\hline Pluvialis apricaria & $1-$ & 4 & & 5 & & 12 & & 4 & $1+$ & 6 & 31 & 0.34 \\
\hline Philomachus pugnax & $1-$ & 2 & & 2 & & 4 & & 1 & $1+$ & 8 & 17 & 0.19 \\
\hline Anas platyrhynchos & & 36 & $1-$ & 7 & & 17 & & 8 & & 4 & 72 & 0.80 \\
\hline Lyrurus tetrix & & 42 & $1-$ & 4 & & 22 & & 4 & & 4 & 76 & 0.85 \\
\hline Turdus iliacus & $1-$ & 2 & & 7 & & 4 & & 1 & & & 14 & 0.16 \\
\hline Clethrionomys glareolus & & 131 & & $\overline{6} \overline{9}$ & & 62 & & 17 & & 8 & 287 & 3.19 \\
\hline Scolopax rusticola & & 12 & & 2 & & 4 & & 4 & & 1 & 23 & 0.26 \\
\hline Mustela erminea & & 10 & & 6 & & 1 & & 4 & & 1 & 22 & 0.24 \\
\hline Mustela nivalis & & 11 & & 8 & & 1 & & 1 & & 1 & 22 & 0.24 \\
\hline Turdus philomelos & & 7 & & 3 & & 5 & & & & 1 & 16 & 0.18 \\
\hline Turdus merula & & 3 & & 3 & & 5 & & 3 & & & 14 & 0.16 \\
\hline Tetrao urogallus & & 8 & & & & & & 2 & & 1 & 11 & 0.12 \\
\hline Corvus corax & & 3 & & & & 3 & & 4 & & 1 & 11 & 0.12 \\
\hline
\end{tabular}




\section{Appendix 2.}

Continuation.

Pokračovanie.

\begin{tabular}{|c|c|c|c|c|c|c|c|}
\hline $\begin{array}{l}\text { municipality / samospráva } \\
\text { taxa / taxón }\end{array}$ & Malvik & Stjordal & Agdenes & Snillfjord & Ørland & $\Sigma$ & $\%$ \\
\hline Sorex araneus & 2 & 1 & 4 & 1 & 1 & 9 & 0.10 \\
\hline Bucephala clangula & 6 & 1 & 1 & 1 & & 9 & 0.10 \\
\hline Numenius phaeopus & 1 & 3 & 5 & & & 9 & 0.10 \\
\hline Asio otus & 7 & 1 & & & & 8 & 0.09 \\
\hline Pica pica & 4 & 1 & & 1 & 2 & 8 & 0.09 \\
\hline Accipiter gentilis & 7 & & & & & 7 & 0.08 \\
\hline Falco columbarius & 3 & 1 & & 2 & & 6 & 0.07 \\
\hline Actitis hypoleucos & 4 & & 1 & 1 & & 6 & 0.07 \\
\hline Lymnocryptes minimus & & & 4 & 1 & 1 & 6 & 0.07 \\
\hline Anthus pratensis & 1 & & 5 & & & 6 & 0.07 \\
\hline Sturnus vulgaris & & & 1 & 4 & 1 & 6 & 0.07 \\
\hline Garrulus glandarius & 4 & & 1 & 1 & & 6 & 0.07 \\
\hline Mammalia & 2249 & $1+\quad 1152$ & 641 & 274 & 81 & 4397 & 48.93 \\
\hline Aves & 400 & 114 & 323 & 241 & $1+$ & 1165 & 12.96 \\
\hline Amphibia, Pisces & 1535 & 597 & $1+\quad 1001$ & 182 & 108 & 3423 & 38.09 \\
\hline Invertebrata & 0 & 0 & 1 & 0 & 1 & 2 & 0.02 \\
\hline$\Sigma$ & 4184 & 1863 & 1966 & 697 & 277 & 8987 & 100.00 \\
\hline $\mathbf{H}^{\prime}$ & 2.10 & 1.69 & 1.91 & 2.71 & 2.78 & 2.22 & \\
\hline
\end{tabular}

Other species (municipality-number) / ostatné druhy (okres-počet): Sorex minutus (3-1), Neomys fodiens (3-1), Microtus oeconomus (2-2; 1-3), Martes martes (3-1), Neovison vison (3-1), Artiodactyla sp. (3-1), Gavia sp. (2-2), Ardea cinerea (4-1), Anas penelope (3-1; 4-1), Anas querquedula (4-1), Anas acuta (3-3; 5-1), Aythya fuligula (2-2), Melanitta fusca (4-1; 5-1), Somateria mollissima (2-1; 4-1), Mergus serrator (4-1), Mergus merganser (4-2), Anatidae (2-5), Accipiter nisus (2-2), Buteo lagopus (2-4), Pandion haliaetus (2-1), Falco peregrinus (2-1), Falco tinnunculus (2-2), Lagopus muta (2-1; 3-4), Phasianus colchicus (4-1; 5-1), Gallus gallus dom. (4-1), Rallus aquaticus (5-1), Crex crex (2-1), Gallinula chloropus (3-1), Fulica atra (3-1), Charadrius dubius (4-1), Charadrius hiaticula (5-3), Charadrius morinellus (4-2), Calidris maritima (4-1), Calidris sp. (2-1), Tringa nebularia (2-3), Tringa glareola (2-1), Tringa ochropus (2-3), Tringa sp. (5-1), Numenius arquata (3-1; 5-1), Limosa lapponica (3-2), Gallinago media (2-1), Limicolae $(2-1 ; 3-1 ; 4-1)$, Larus ridibundus (2-2; 5-3), Larus fuscus $(2-1 ; 4-2 ; 5-1)$, Larus marinus (4-1), Rissa tridactyla (4-3; 5-2), Sterna paradisaea (5-1), Alca torda (1-1; 4-2), Uria aalge (4-1), Charadriiformes (2-5; 5-1), Columba livia dom. (2-2; 4-1), Cuculus canorus (5-1), Bubo bubo (2-4; 3-1), Surnia ulula (2-3), Strix aluco (2-1), Picus canus (2-2; 4-1), Dendrocopos major (3-1), Dendrocopos leucotos (3-1), Alauda arvensis (5-1), Delichon urbica (2-1), Anthus petrosus (3-2), Prunella modularis (3-1), Phylloscopus trochilus (3-1), Oenanthe oenanthe (2-1), Phoenicurus phoenicurus (2-1), Erithacus rubecula (1-2), Turdus torquatus (3-1), Turdus viscivorus (2-1), Turdus sp. (2-1), Periparus ater (3-1), Cyanistes caeruleus (2-1), Troglodytes troglodytes (3-1), Emberiza citrinella (2-1; 3-1), Emberiza schoeniclus (3-2; 4-1), Plectrophenax nivalis (1-1), Calcarius lapponicus (1-1), Fringilla montifringilla (2-1; 1-3), Carduelis spinus (2-1), Carduelis flavirostris (1-1; 4-1), Carduelis hornemanni (3-1), Loxia curvirostra (2-1), Loxia pytyopsittacus (3-1), Perisoreus infaustus (2-3; 1-1), Nucifraga caryocatactes (1-1), Coloeus monedula (2-4), Passeriformes (2-1), Aves (2-1; 1-1), Aves sp. juv. (2-3; 1-2; 3-4; 4-3; 5-4), Bufo bufo (5-2), Salmonidae (2-1; 1-1; 4-1; 5-2), Pisces (3-4; 4-2), Coleoptera (3-1), Decapoda (5-1) 
Slovak Raptor Journal 2016, 0: 0-0. DOI: 10.1515/srj-2016-0005.

(C) Raptor Protection of Slovakia (RPS)

Appendix 3.

Diet of Bubo bubo on the islands. See Appendix 1 for more details.

Vzorky potravy Bubo bubo z ostrovov. Pre viac inforácií vid'Appendix 1.

\begin{tabular}{|c|c|c|c|c|c|c|c|c|c|c|c|c|c|c|}
\hline \multirow{2}{*}{$\begin{array}{l}\text { island / ostrov } \\
\text { taxa / taxón } \\
\text { Arvicola amphibius }\end{array}$} & \multicolumn{2}{|c|}{ Halmøya } & \multicolumn{2}{|c|}{ Ramsøya } & \multicolumn{2}{|c|}{ Linesøya } & \multicolumn{2}{|c|}{ Storfosna } & \multicolumn{2}{|c|}{ Hitra } & \multicolumn{2}{|c|}{ Frøya } & \multirow{2}{*}{$\begin{array}{c}\sum \\
2104\end{array}$} & \multirow{2}{*}{\begin{tabular}{c|}
$\%$ \\
8.42
\end{tabular}} \\
\hline & $1+$ & 2059 & $5-$ & 6 & $6-$ & 1 & 4- & 1 & $2-$ & 36 & $6-$ & 1 & & \\
\hline Mustela erminea & $1+$ & 39 & & 6 & 1- & 0 & & 1 & & 2 & $1-$ & 0 & 48 & 0.19 \\
\hline Microtus agrestis & & 9073 & $1+$ & 1989 & $1+$ & 1557 & $6-$ & 2 & $7-$ & 4 & 8- & 2 & 12,627 & 50.52 \\
\hline Lemmus lemmus & & 513 & $2+$ & 356 & $3-$ & 9 & 3- & 0 & 4- & 1 & $5-$ & 0 & 879 & 3.52 \\
\hline Clethrionomys rufocanus & $1-$ & 19 & $2+$ & 35 & $1-$ & 0 & & & $1-$ & 0 & $1-$ & 0 & 54 & 0.22 \\
\hline Cepphus grylle & & 14 & $1+$ & 10 & & 2 & & 1 & & 4 & & 2 & 33 & 0.13 \\
\hline Tringa totanus & $2-$ & 0 & $1+$ & 7 & & 3 & & & & 3 & & 4 & 17 & 0.07 \\
\hline Sorex araneus & $1-$ & 37 & $2+$ & 68 & $2+$ & 57 & & & $2-$ & 0 & $2-$ & 0 & 162 & 0.65 \\
\hline Turdus iliacus & $1-$ & 11 & $1+$ & 14 & $1+$ & 12 & & 1 & $1+$ & 9 & & 2 & 49 & 0.20 \\
\hline Turdus merula & $2-$ & 10 & $1+$ & 14 & $1-$ & 0 & & 4 & $1+$ & 13 & $1+$ & 16 & 57 & 0.23 \\
\hline Turdus pilaris & $2-$ & 16 & $1+$ & 22 & & 16 & $1+$ & 9 & $1+$ & 27 & $1+$ & 18 & 108 & 0.43 \\
\hline Calidris alpina & $1-$ & 10 & & 2 & $2+$ & 20 & & & & 1 & & & 33 & 0.13 \\
\hline Asio otus & $2-$ & 1 & & 2 & $2+$ & 13 & & & & 2 & & 1 & 19 & 0.08 \\
\hline Asio flammeus & $1-$ & 35 & & 12 & $1+$ & 15 & & & $1+$ & 14 & & 4 & 80 & 0.32 \\
\hline Lyrurus tetrix & $1-$ & 47 & & 18 & $1+$ & 18 & & 1 & $1+$ & 18 & $1-$ & 3 & 105 & 0.42 \\
\hline Charadrius hiaticula & $2-$ & 5 & & 3 & $1+$ & 10 & $1+$ & 9 & $1+$ & 9 & & 2 & 38 & 0.15 \\
\hline Melanitta fusca & & 8 & & & & & $1+$ & 8 & & 2 & & 3 & 21 & 0.08 \\
\hline Carduelis flavirostris & $2-$ & 1 & & 1 & & 4 & $2+$ & 19 & & 1 & & 2 & 28 & 0.11 \\
\hline Philomachus pugnax & $1-$ & 12 & & 3 & & 1 & $2+$ & 13 & & 5 & $1+$ & 14 & 48 & 0.19 \\
\hline Mus cf. musculus & $3-$ & 2 & $2-$ & 0 & $1-$ & 1 & $4+$ & 62 & & 3 & $1+$ & 17 & 85 & 0.34 \\
\hline Erinaceus europaeus & $5-$ & 0 & 3- & 0 & $2-$ & 0 & $3+$ & 45 & $2+$ & 71 & $1+$ & 36 & 152 & 0.61 \\
\hline Lepus timidus & $5-$ & 2 & & 37 & $3-$ & 0 & $3+$ & 58 & $3+$ & 162 & $1+$ & 57 & 316 & 1.26 \\
\hline Anas platyrhynchos & 3- & 21 & $1-$ & 16 & $1-$ & 18 & $2+$ & 34 & $1+$ & 52 & $2+$ & 132 & 273 & 1.90 \\
\hline Haematopus ostralegus & & 61 & & 11 & $1-$ & 6 & $2+$ & 16 & $1+$ & 17 & $1+$ & 21 & 132 & 0.53 \\
\hline Numenius arquata & $2-$ & 6 & $1-$ & 3 & & 10 & $1+$ & 9 & $1+$ & 11 & $2+$ & 30 & 69 & 0.28 \\
\hline Larus canus & $2-$ & 64 & $2-$ & 19 & $2-$ & 10 & $3+$ & 73 & $2+$ & 97 & $2+$ & 162 & 425 & 1.70 \\
\hline Larus argentatus & 4- & 19 & $1-$ & 34 & $1-$ & 43 & $1+$ & 39 & $2+$ & 206 & $3+$ & 307 & 648 & 2.59 \\
\hline Larus marinus & 3- & 3 & & 7 & & 6 & & 4 & $2+$ & 34 & $2+$ & 40 & 94 & 0.38 \\
\hline Alle alle & $3-$ & 13 & $1+$ & 31 & & 16 & $1+$ & 10 & $2+$ & 78 & $1+$ & 25 & 173 & 0.69 \\
\hline Corvus cornix & $1-$ & 84 & $1-$ & 20 & $1-$ & 12 & $1+$ & 14 & $1+$ & 41 & $1+$ & 57 & 228 & 0.91 \\
\hline Corvus corax & $1-$ & 11 & & 10 & & 2 & $1+$ & 6 & $1+$ & 10 & & 7 & 46 & 0.18 \\
\hline Sturnus vulgaris & $1-$ & 14 & & 4 & & 1 & $1+$ & 8 & $1+$ & 9 & & 4 & 40 & 0.16 \\
\hline Pica pica & $1-$ & 2 & & 3 & & & & 1 & $1+$ & 7 & & 2 & 15 & 0.06 \\
\hline Garrulus glandarius & $1-$ & 1 & & 1 & & & & & $1+$ & 7 & & 2 & 11 & 0.04 \\
\hline Larus fuscus & $1-$ & 0 & & & & & & 2 & $1+$ & 6 & & & 8 & 0.03 \\
\hline Fratercula arctica & & 189 & $2-$ & 10 & $2-$ & 6 & & 5 & $2+$ & 87 & $1-$ & 20 & 317 & 1.27 \\
\hline Clethrionomys glareolus & $1-$ & 86 & 3- & 4 & $3-$ & 3 & $1-$ & 2 & $3+$ & 252 & 3- & 2 & 349 & 1.40 \\
\hline Sorex minutus & $1-$ & 2 & & 2 & & & & & $1+$ & 7 & & 1 & 12 & 0.05 \\
\hline Mustela nivalis & & 12 & & 2 & & & & & $1+$ & 6 & & & 20 & 0.08 \\
\hline Anas acuta & $1-$ & 1 & & & & 1 & & & $1+$ & 7 & & 4 & 13 & 0.05 \\
\hline Anas crecca & $1-$ & 80 & 1- & 12 & $1-$ & 13 & & 2 & $2+$ & 64 & $2+$ & 91 & 262 & 1.50 \\
\hline Anas penelope & $1-$ & 13 & $1-$ & 2 & & 3 & & 1 & $1+$ & 20 & $2+$ & 24 & 63 & 0.25 \\
\hline Mergus serrator & $1-$ & 19 & $1-$ & 3 & $1-$ & 2 & & 1 & $2+$ & 30 & $1+$ & 20 & 75 & 0.30 \\
\hline Bucephala clangula & $2-$ & 3 & & 1 & & 1 & & 1 & $1+$ & 12 & $2+$ & 20 & 38 & 0.15 \\
\hline Scolopax rusticola & $2-$ & 13 & & 17 & & 8 & & 1 & $3+$ & 64 & $1+$ & 20 & 123 & 0.49 \\
\hline Gallinago gallinago & $2-$ & 59 & $1-$ & 25 & $1+$ & 42 & & 10 & $2+$ & 108 & $2+$ & 87 & 331 & 1.32 \\
\hline Rattus norvegicus & $5-$ & 0 & 3- & 0 & $3-$ & 0 & $1-$ & 0 & $3+$ & 123 & $2+$ & 86 & 209 & 0.84 \\
\hline Neovison vison & $2-$ & 0 & & 1 & & & & & $1+$ & 11 & $1+$ & 7 & 19 & 0.08 \\
\hline Lagopus lagopus & $1-$ & 83 & & 30 & $1-$ & 13 & & 2 & $1+$ & 57 & $2+$ & 73 & 258 & 1.30 \\
\hline Pluvialis apricaria & $1-$ & 31 & $1-$ & 9 & & 10 & & 5 & $1+$ & 27 & $2+$ & 45 & 127 & 0.51 \\
\hline Vanellus vanellus & $2-$ & 20 & $1-$ & 9 & $2-$ & 2 & $4+$ & 67 & $1+$ & 18 & $1+$ & 25 & 141 & 0.56 \\
\hline Turdus philomelos & $1-$ & 13 & & 12 & & 4 & & 5 & $1+$ & 11 & $1+$ & 13 & 58 & 0.23 \\
\hline Neomys fodiens & $3-$ & 0 & $1-$ & 0 & & & & & & 2 & $3+$ & 37 & 39 & 0.16 \\
\hline Rana temporaria & & 1183 & $1-$ & 219 & $1+$ & 333 & 4- & 0 & $6-$ & 0 & $2+$ & 555 & 2290 & 9.16 \\
\hline
\end{tabular}


Appendix 3.

Continuation.

Pokračovanie.

\begin{tabular}{|c|c|c|c|c|c|c|c|c|c|c|}
\hline \multirow{2}{*}{$\begin{array}{l}\text { island / ostrov } \\
\text { taxa / taxón } \\
\text { Ardea cinerea }\end{array}$} & \multicolumn{2}{|c|}{ Halmøya } & \multirow{2}{*}{$\begin{array}{r}\text { Ramsøya } \\
4\end{array}$} & Linesøya & Storfosna & Hitra & \multicolumn{2}{|c|}{ Frøya } & $\Sigma$ & \multirow{2}{*}{$\begin{array}{ll}\% \\
0.08\end{array}$} \\
\hline & $2-$ & 0 & & 1 & & 5 & $1+$ & 11 & 21 & \\
\hline Phasianus colchicus & & & & & & & $1+$ & 6 & 6 & 0.02 \\
\hline Limosa lapponica & & 17 & & & 2 & 3 & $1+$ & 8 & 30 & 0.12 \\
\hline Rissa tridactyla & $1-$ & 9 & 2 & 6 & 2 & & $1+$ & 8 & 27 & 0.11 \\
\hline Sterna hirundo & $1-$ & 1 & 2 & & 1 & & $1+$ & 10 & 14 & 0.06 \\
\hline Sterna paradisaea & $1-$ & 7 & 6 & 1 & 2 & 3 & $1+$ & 8 & 27 & 0.11 \\
\hline Salmonidae & $1-$ & 0 & & & & & $1+$ & 7 & 7 & 0.03 \\
\hline Pisces & $1-$ & 44 & 16 & $1-$ & 6 & 8 & $1+$ & 21 & 99 & 0.40 \\
\hline Actitis hypoleucos & $1-$ & 0 & 3 & & & 4 & & 1 & 8 & 0.03 \\
\hline Limosa limosa & $1-$ & 0 & & 1 & & 5 & & 5 & 11 & 0.04 \\
\hline Columba palumbus & $2-$ & 2 & 7 & 6 & 2 & 5 & & 1 & 23 & 0.09 \\
\hline Decapoda & $1-$ & 1 & 3 & 1 & & & & 5 & 10 & 0.04 \\
\hline Calidris maritima & & 38 & 11 & 10 & & $1-$ & $1-$ & 1 & 60 & 0.24 \\
\hline Mergus merganser & & 38 & 4 & 2 & & 6 & & 7 & 57 & 0.23 \\
\hline Somateria mollissima & & 25 & 3 & 1 & 4 & 7 & & 7 & 47 & 0.19 \\
\hline Uria aalge & & 29 & 3 & 1 & 1 & 5 & & 6 & 45 & 0.18 \\
\hline Bubo bubo & & 18 & & 1 & 2 & 2 & & 7 & 30 & 0.12 \\
\hline Numenius phaeopus & & 12 & & 1 & 2 & 5 & & 2 & 22 & 0.09 \\
\hline Uria lomvia & & 12 & 2 & & & 4 & & 3 & 21 & 0.08 \\
\hline Lagopus muta & & 10 & 5 & 1 & & & & & 16 & 0.06 \\
\hline Falco tinnunculus & & 7 & 1 & 4 & & 1 & & 2 & 15 & 0.06 \\
\hline Anas querquedula & & 3 & 2 & 2 & & 3 & & 2 & 12 & 0.05 \\
\hline Aythya marila & & 12 & & & & & & & 12 & 0.05 \\
\hline Mammalia & & 846 & 2507 & 1628 & 171 & 683 & 3- & 248 & 17,083 & 68.35 \\
\hline Aves & $1-$ & 411 & 1- $\quad 490$ & 1- 407 & 424 & $2+1318$ & $2+$ & 1450 & 5500 & 22.00 \\
\hline Amphibia, Pisces & & 227 & 235 & 337 & 3- & 4- & $2+$ & 583 & 2396 & 9.59 \\
\hline Invertebrata & 1- & 1 & 4 & 2 & 1 & 1 & $1+$ & 7 & 16 & 0.06 \\
\hline $\bar{\Sigma}$ & & 485 & 3236 & 2374 & 602 & 2010 & & 2288 & 24,995 & 100.00 \\
\hline $\mathrm{H}^{\prime}$ & & 1.58 & 1.84 & 1.60 & 3.22 & 3.47 & & 3.15 & 2.36 & \\
\hline
\end{tabular}

Other species (municipality-number) / ostatné druhy (okres-počet): Sciurus vulgaris (1-1), Canis domesticus (1-1; 6-2), Felis catus dom. (5-2), Ovis ammon aries $(2-1 ; 5-1)$, Gavia stellata (2-1), Podiceps auritus $(1-1 ; 6-1)$, Tachybaptus ruficollis (3-1), Fulmarus glacialis (1-1; 5-1; 6-1), Phalacrocorax carbo (6-1), Phalacrocorax aristotelensis (5-1), Anser fabalis (5-1; 6-1), Anas clypeata (6-2), Aythya fuligula (1-2; 4-1), Melanitta nigra (5-2), Clangula hyemalis (4-2; 5-1; 6-1), Tadorna tadorna (2-1), Anatidae (1-19; 2-3; 4-4; 5-6; 6-2), Accipiter gentilis (1-3), Accipiter nisus (1-3; $4-1 ; 5-3)$, Buteo lagopus $(1-1 ; 4-1 ; 5-1)$, Falco peregrinus $(5-2 ; 6-2)$, Falco columbarius $(1-3 ; 2-1 ; 5-1)$, Tetrao urogallus (2-1; 6-1), Coturnix coturnix (1-1), Gallus gallus dom. (6-2), Rallus aquaticus (1-4; 2-1; 4-1; 5-1; 6-1), Porzana porzana (5-1), Crex crex (1-1; 2-1; 5-1; 6-1), Gallinula chloropus (5-1; 6-3), Fulica atra (1-1; 5-1; 6-2), Charadrius morinellus (4-2), Calidris canutus (1-1; 5-1), Calidris ferruginea (2-1; 3-1), Tringa nebularia (3-1), Tringa glareola (1-3; 2-1; 4-1; 6-1), Tringa ochropus (6-1), Gallinago media (2-1; 4-1; 5-2), Lymnocryptes minimus (2-2; 5-3; 6-1), Limicolae $(1-7 ; 2-3 ; 3-1 ; 5-1 ; 6-1)$, Stercorarius paraziticus $(1-3 ; 2-1 ; 6-1)$, Stercorarius pomarinus (4-1), Stercorarius skua (5-1), Larus ridibundus (1-3; 4-1), Alca torda (4-2; 6-1), Columba livia dom. (1-2; 2-2; 5-1; 6-3), Cuculus canorus (1-2; 3-2; 5-2), Bubo scandiacus (3-1; 6-1), Surnia ulula (5-1), Aegolius funereus (1-3), Strix aluco (2-1), Picus canus (5-1), Hirundo rustica (1-2), Delichon urbica (1-2), Anthus pratensis (1-1; 2-1; 3-1; 6-1), Anthus petrosus (1-3), Anthus sp. (4-1), Motacilla alba (1-4), Bombycilla garrulus (6-1), Lanius excubitor (5-2), Prunella modularis (1-1; 3-1), Sylvia communis (2-1), Sylvia curruca (1-1), Saxicola rubetra (1-1), Oenanthe oenanthe (1-1), Phoenicurus phoenicurus (6-1), Erithacus rubecula (1-2; 2-1; 3-1), Turdus torquatus $(2-2 ; 4-1 ; 5-1 ; 6-1)$, Turdus viscivorus (6-1), Turdus sp. $(5-1 ; 6-2)$, Parus major (1-1), Sitta europaea (1-1), Troglodytes troglodytes (4-1), Cinclus cinclus (2-1), Emberiza citrinella (4-1), Plectrophenax nivalis (1-4; 3-1; 5-1), Fringilla coelebs (1-4; 2-1; 5-1), Carduelis spinus (4-1; 5-2), Carduelis hornemanni (1-7; 4-1), Carduelis sp. (6-3), Pinicola enucleator (1-1; 3-2), Loxia curvirostra (1-1; 3-1; 5-1), Passer domesticus (4-1), Nucifraga caryocatactes (6-1), Coloeus monedula (5-1), Passeriformes (1-1; 2-1; 3-1; 5-1), Passeriformes sp. juv (6-2), Aves (1-14; 5-2; 6-1), Aves sp. juv. (1-62; 2-9; 3-11; 5-22; 6-8), Coleoptera (2-1; 3-1; 4-1; 5-1; 6-1), Bivalvia (6-1) 